\title{
Point Of Sales (POS) Application On Clients of PT. Esensi Solusi Buana
}

\author{
Ria Wulandari*1, Siti Maesaroh ${ }^{2}$, Erwansyah $^{3}$ \\ ${ }^{1,3}$ Program Studi Teknik Informatika Universitas Raharja, ${ }^{2}$ Program Studi Sistem Informasi \\ Universitas Raharja \\ Email : ${ }^{* 1}$ wulandari@ raharja.info, ${ }^{2}$ siti.maesaroh@ raharja.info, ${ }^{3}$ erwansyah@ raharja.info
}

\begin{abstract}
Point of Sales application is a system used for transaction data into the database both by input and output, so that there are no errors in input, output data, and report generation based on the corresponding data, thus it can produce accurate output data. PT Esensi Solusi Buana is a company engaged in the field of technology and information. Based on surveys and interviews with clients of PT Esensi Solusi Buana, it is obtained the information about the operating system that is still manual and less than optimal.This causes frequent errors in recording sales transaction data, archiving that still uses the traditional system, as well as access to obtain information about the transaction history that requires a lot of time. Therefore, the system to be made is an improvement of the system that was previously made for the clients of PT Esensi Solusi Buana. It is expected that with this system, it can minimize errors that may occur. This system is also expected to be able to improve the process of input, output, and report generation, which in turn can help data collection of sales transactions on the clients of PT Esensi Solusi Buana.
\end{abstract}

Keywords - Point Of Sales, Input, Output, Application

\section{INTRODUCTION}

In line with the development of the globalization era, especially in the economic sector, competition in business has become tighter and more competitive. This of course requires business people to be able to increase selling power, both from products or services produced and in terms of information systems that are able to compete in managing and running a company. There are so many ways in which business people can survive, have competitiveness and continue to improve the services provided for customers.

In the business world, the sales process is a process that is very important to support the company's business continuity. Along with the high frequency of the sales process, the provision of information that can support and increase sales is really needed by each business sector in order to face competition and further business challenges. Furthermore, with the development of increasingly sophisticated technology, business people need to have a system to support their business activities. A system is needed to facilitate business people in managing and monitoring sales transactions in a more orderly, accurate and real time manner.

PT Esensi Solusi Buana is a company engaged in the field of technology and information that has several clients engaged in F\&B (Food and Beverage) Restaurants. All this time, sales management activities at PT Esensi Solusi Buana's clients are still done manually by using paper media and then transferred to the computer. However, sales order transaction information and direct sales transactions are still stored on paper, causing problems. Problems occur in the recording process which is still done manually. Therefore,it often spends a lot of books every time there is a transaction and lack of accuracy in data collection and procurement of goods, data of goods and transaction data 
are inaccurate and have an effect on the process of making profit reports ${ }^{[10]}$. To overcome this problem, a new system is needed that it makes easy to order, sell and report-sales report ${ }^{[5]}$. One form of system that is commonly used in a company engaged in trading is the Point of Sales (POS) System. POS can be translated freely into the cashier system, namely sales-oriented activities that occur in the retail business sector ${ }^{[4]}$. One of the reasons made for the design of point of sales (POS) application is to be able to facilitate the recording of sales transactions, help the sales administration operational activities and speed up the process of service to customers ${ }^{[3]}$.

\section{RESEARCH METHOD}

\section{A. Method of Analyzing Data}

In analyzing a system, generally, several aspects will be carried out including performance, information, economy, application security, efficiency and customer service. The analysis conducted by the writer uses PIECES Analysis (Performance, Information, Economy, Control, Efficiency and Service). PIECES analysis is very important to do before developing an information system because in this analysis, usually, several main problems and problems that are symptomatic of the main problemwill be found. This method uses six evaluation variables, namely: ${ }^{[2]}$.

\section{1) Performance}

Performance is the first variable in the PIECES analysis method where it has an important role to assess whether the process or procedure is still possible to be improved, and see to what extent and how reliable an information system is in processing to produce the desired goals.

\section{2) Information}

Assessing whether the existing procedures can still be improved so that the quality of information produced is getting better. The information presented must truly have useful value.

\section{3) Economy}

Assessing whether the existing procedures can still be improved (the value) or reduced the procurement costs.

\section{4) Control}

Assessing whether the existing procedures can still be improved so that the quality of control is getting better, and its ability to detect errors / fraud is getting better too.

\section{5) Efficiency}

Assessing whether the existing procedures can still be improved, so thatthe operating efficiency enhancement can be achieved, and must be superior to the manual system.

\section{6) Service}

Assessing whether the existing procedures can still be improved in their ability to achieve improved service quality. Make the quality of service very user friendly for endusers so that users get good quality service. 
Table 1. PIECES Analysis for the Running System

\begin{tabular}{|c|c|c|c|}
\hline NO & $\begin{array}{l}\text { TYPES OF } \\
\text { ANALYSIS }\end{array}$ & $\begin{array}{c}\text { WEAKNESS OF RUNNING } \\
\text { SYSTEM }\end{array}$ & PROPOSED SYSTEM \\
\hline 1. & Performance & $\begin{array}{l}\text { Handling of sales } \\
\text { transactions and sales reports } \\
\text { are still manual, so there are } \\
\text { still often loss or damage of } \\
\text { the report. } \\
\text { Inappropriate data input has } \\
\text { an impact on the calculation } \\
\text { results for payment, so that it } \\
\text { has the potential to cause } \\
\text { customer complaints. }\end{array}$ & $\begin{array}{l}\text { All reports will be stored in } \\
\text { the database. }\end{array}$ \\
\hline 2. & Information & $\begin{array}{l}\text { Data - the results of reports } \\
\text { or complaints that are still } \\
\text { stored in the form of } \\
\text { archives, making it } \\
\text { vulnerable to data loss or } \\
\text { damage. } \\
\text { To find data and reports also } \\
\text { require a long time. }\end{array}$ & $\begin{array}{l}\text { Data has been stored in a } \\
\text { database so that it can be } \\
\text { seen anytime and from } \\
\text { anywhere. }\end{array}$ \\
\hline 3. & Economy & $\begin{array}{l}\text { There is inefficiency because } \\
\text { it requires a large enough } \\
\text { cost to buy paper and } \\
\text { stationery in the long run. }\end{array}$ & $\begin{array}{l}\text { With this system, it can } \\
\text { reduce the cost of } \\
\text { purchasing office stationery } \\
\text { so that it can reduce } \\
\text { operational costs. }\end{array}$ \\
\hline 4. & Control & $\begin{array}{l}\text { There is no protection for } \\
\text { data because all data is stored } \\
\text { in archives and no } \\
\text { restrictions on access rights } \\
\text { that result in unrelated parties } \\
\text { being able to access the data } \\
\text { which causes data loss or } \\
\text { damage. }\end{array}$ & $\begin{array}{l}\text { Data is stored in a system } \\
\text { application that requires } \\
\text { authentication to enter the } \\
\text { system so that it can } \\
\text { minimize unwanted things. }\end{array}$ \\
\hline 5. & Efficiency & $\begin{array}{l}\text { It still takes a long time in } \\
\text { the process of making reports } \\
\text { due to conditions that are not } \\
\text { always updated. }\end{array}$ & $\begin{array}{l}\text { There is a menu of search } \\
\text { column with several } \\
\text { conditions making it easier } \\
\text { to search. }\end{array}$ \\
\hline 6. & Service & $\begin{array}{l}\text { The current system is still } \\
\text { experiencing many } \\
\text { shortcomings, especially in } \\
\text { terms of the submission of } \\
\text { reports that requires a long } \\
\text { time. }\end{array}$ & $\begin{array}{l}\text { Submission of reports can } \\
\text { be done anytime, anywhere } \\
\text { because of conditions that } \\
\text { are always updated. }\end{array}$ \\
\hline
\end{tabular}

\section{B. Method of Designing System}

Using various tools in designing the proposed system, starting from the Visual Paradigm as a tool in the design of the Unified Modeling Language (UML) which will be outlined in the stages of making Use Case Diagrams, Sequence Diagrams, Activity Diagrams, and Class Diagrams, PHP as a Programming Language in system design, Yii2 as a Framework from PHP, MySQL as a Database Management System (DBMS). 


\section{Use Case Diagram of the Running System}

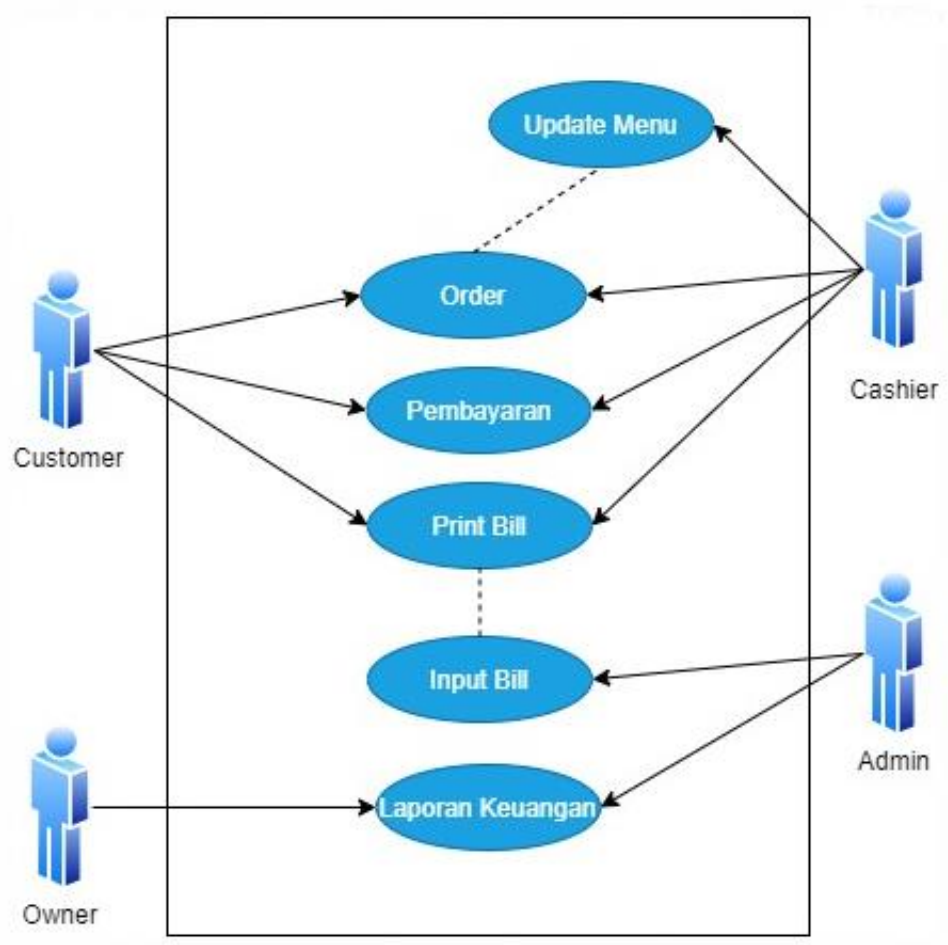

Figure 1. Use Case Diagram of the Running System

Based on Figure 1. Use Case Diagram that is currently running is explained:

1) System : 1 System that includes activities on the point of salesapplication.

2) Actor : :4 actors who carry out activities namely: Owner, Admin, Customer

3) Use Cases : :6 Use Cases commonly used by actors

\section{Literature Review}

The followings are the researches that have been carried out and have correlation with the research that will be discussed, as follows:

1) "Web-based Point of Sales information system on Colony Amaranta Bekasi". Sapto Catur Cahyodi and Rita Wahyuni Arifin $2017^{[1]}$. The research explains how to design an information system that was built to record sales transactions and process data at the Amaranta Colony clinic and spa to help run operational activities and speed up the service process from the registration process to payment so that the services can be improved.

2) "Web-based Point of Sales (POS) application design using the system development life cycle method". Titania Grawidi Yuarita and Fitri Mariska (Journal of information technology \& management volume 3, number 2, July - December 2017 ${ }^{[7]}$. The research explains how this application was developed using the PHP programming language and MySql database. The results of this study are structured applications designed to process sales data.

3) "Development of an Integrated Point of Sales Information System in the Scope of the Restaurant and Its Branches". Annisa Septiana Sani, Fajar Pradana, and Denny Sagita Rusdianto $(2018)^{[8]}$. This study has an objective to build an integrated point of sales information system in the scope of the restaurant and its branches with the aim that the owner can know the development of his restaurant activities in real time and the owner does not have to check every branch in every day to request records of transactions 
that have been carried out for one full day, but only by accessing the system connected to the internet to know all the activities that occur at all outlets.

4) "Design and Build a Point of Sales Distro Management System Application Using the React Native Framework". Putu Dika Arta Wiguna, I Putu Agus Swastika, and I Putu Satwika $(2018)^{[11]}$. According to the Handmade distro owner in Denpasar, in the business process, the distro experienced several obstacles, including difficulties in management and checking of product stock, difficulties in recording sales transactions, difficulties in clothing payment management and others. According to him, this happened because all the processes carried out are still manual by using notebooks or using Microsoft Excel applications.

5) "Point of Sales (POS) System for Cashiers of Indonesian Food Case Studies" Eq Aliffauzi Susilo (2018) ${ }^{[9]}$. This research is taking a case study on Indonesian Food that has constraints in its business processes, where the owner has to do his own bookkeeping for manually recap. Meanwhile, there is an inefficiently in the business processes in terms of providing food information between the cashier and kitchen workers. Therefore, the research is aimed to build a Pont of Sales (POS) information system. Aiming that the owner can see accurate real time information without making a time-consuming bookkeeping. This POS system was built using the Waterfall method, the design of this POS system uses Data Flow Diagrams (DFD) to describe the processes that occur in the system. The programming language uses PHP and the data base uses MySQL.

6) "Mobile Point of Sale Design and Implementation" Susmini Indriani Lestariningati $(2018)^{[6]}$. This research explains about Mobile POS which is a portable computer device that is used primarily as a destination of POS (Point of Sales) and it is a link to input and output devices such as barcode scanners and thermal printers, which are installed with special software for POS. This research proposes two types of design implementation of Mobile Point of Sale (MPOS), which uses a Raspberry Pi Mini PC and an Android OS Smartphone. Both solutions passed functional tests and a comparison was done between them, which showed that Raspberry Pi had a solution that was more economical but more difficult to develop, less comfortable and less friendly to use than an Android-based Smart Phone implementation.

\section{RESULTS AND DISCUSSION}

Problems that arise include errors in recording sales transaction data due to difficulties in finding existing archives. Accessing so much data requires great precision and accuracy to obtain maximum results, but the work becomes less efficient and prone to errors. Archiving that still uses a traditional system also has an impact on time efficiency. Access to obtain information about the transaction history will require considerable time.

From the background of the problem above, the writer wants to design a sales information system to help the clients of PT. Esensi Solusi Buana in organizing and managing sales information to support the decisions made by the client. The realization of this sales information system is the making of a Point of Sales (POS) application that is able to represent a sales information system that is designed as a whole. Sales information system application used to record sales transactions and handle reports on sales activities. 


\section{A. Use Case Proposed System Diagram}

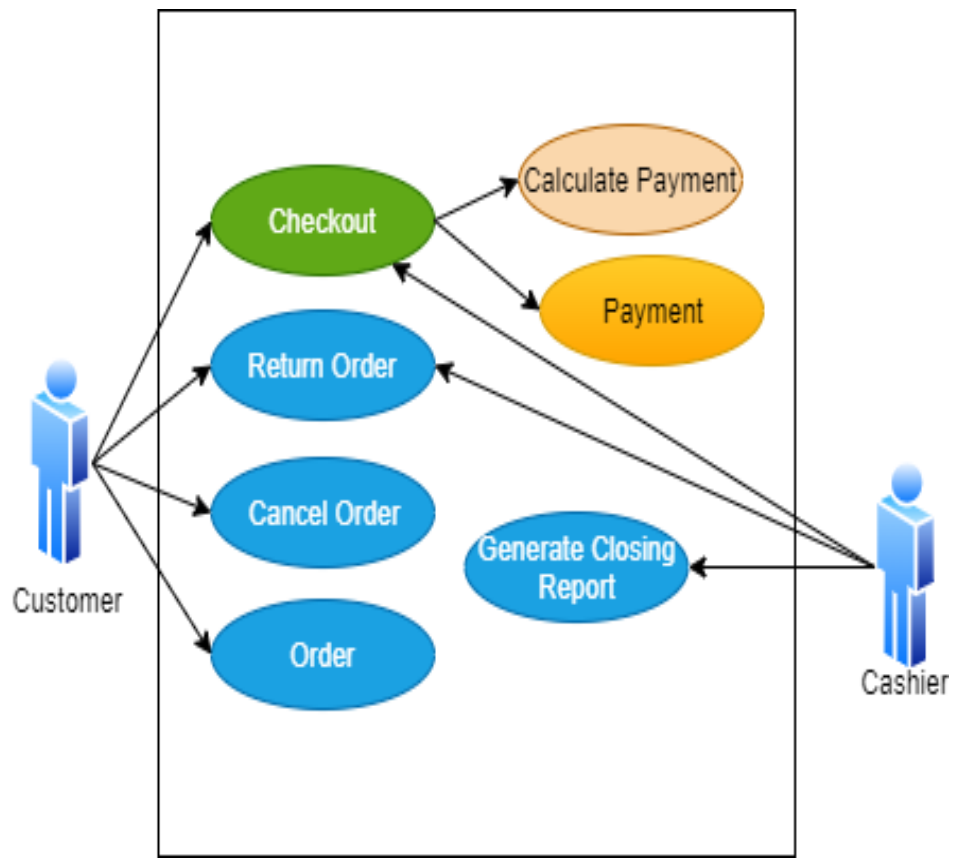

Figure 2. Use Case Diagram Proposed System Diagram

Based on the picture above, it can be concluded as follows:

1) System : 1 System that includes activities on the point of salesapplication.

2) Actor : :2 actors who carry out activities namely: Customer and Cashier

3) Use Cases : 5 Use Cases commonly used by actors.

\section{B. Design The Proposed}

Login Menu Display

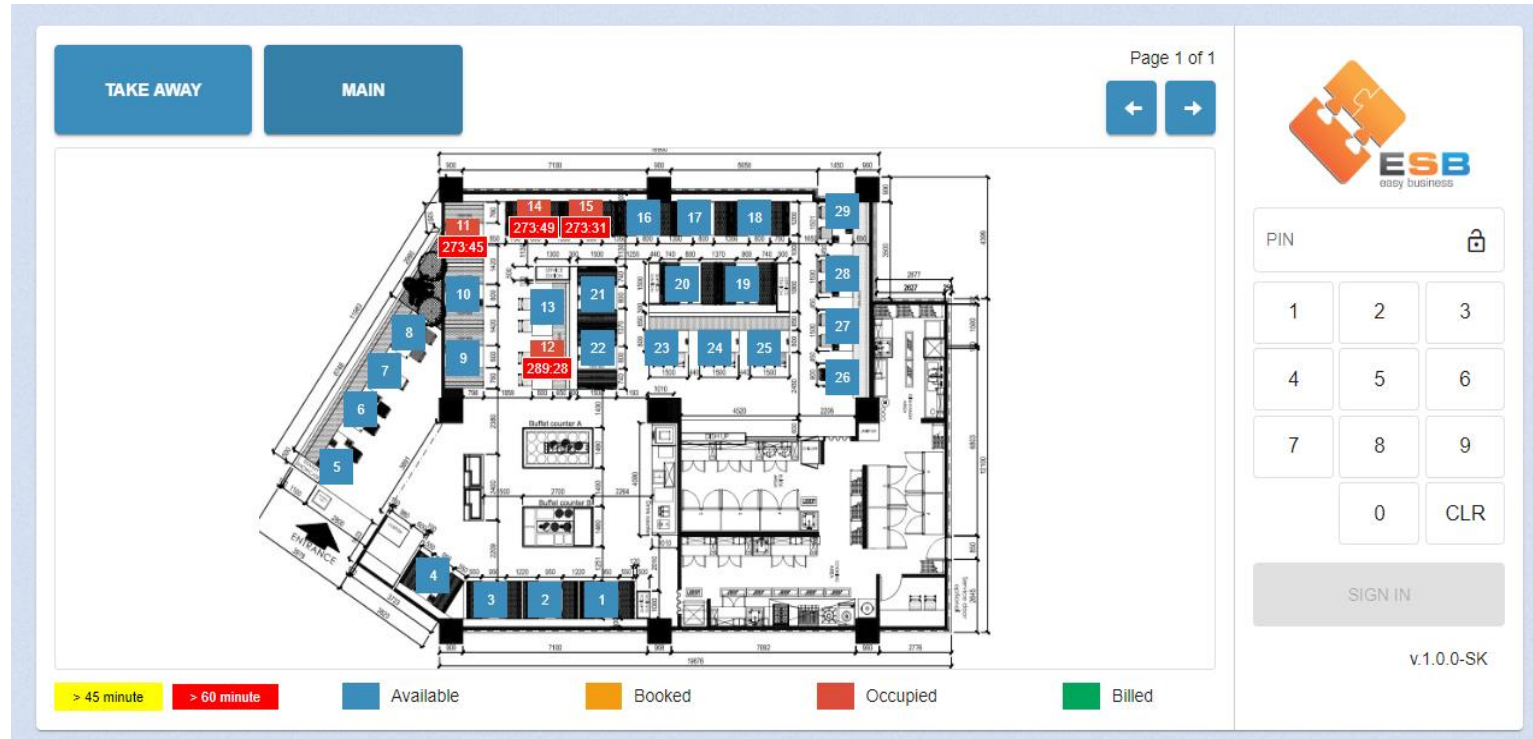

Figure 3. Login Menu Display

In the Login Form there is a text field to enter the PIN then there is a button to Sign in and there is a table layout that is being filled with red or not marked blue. 
Main Page Display

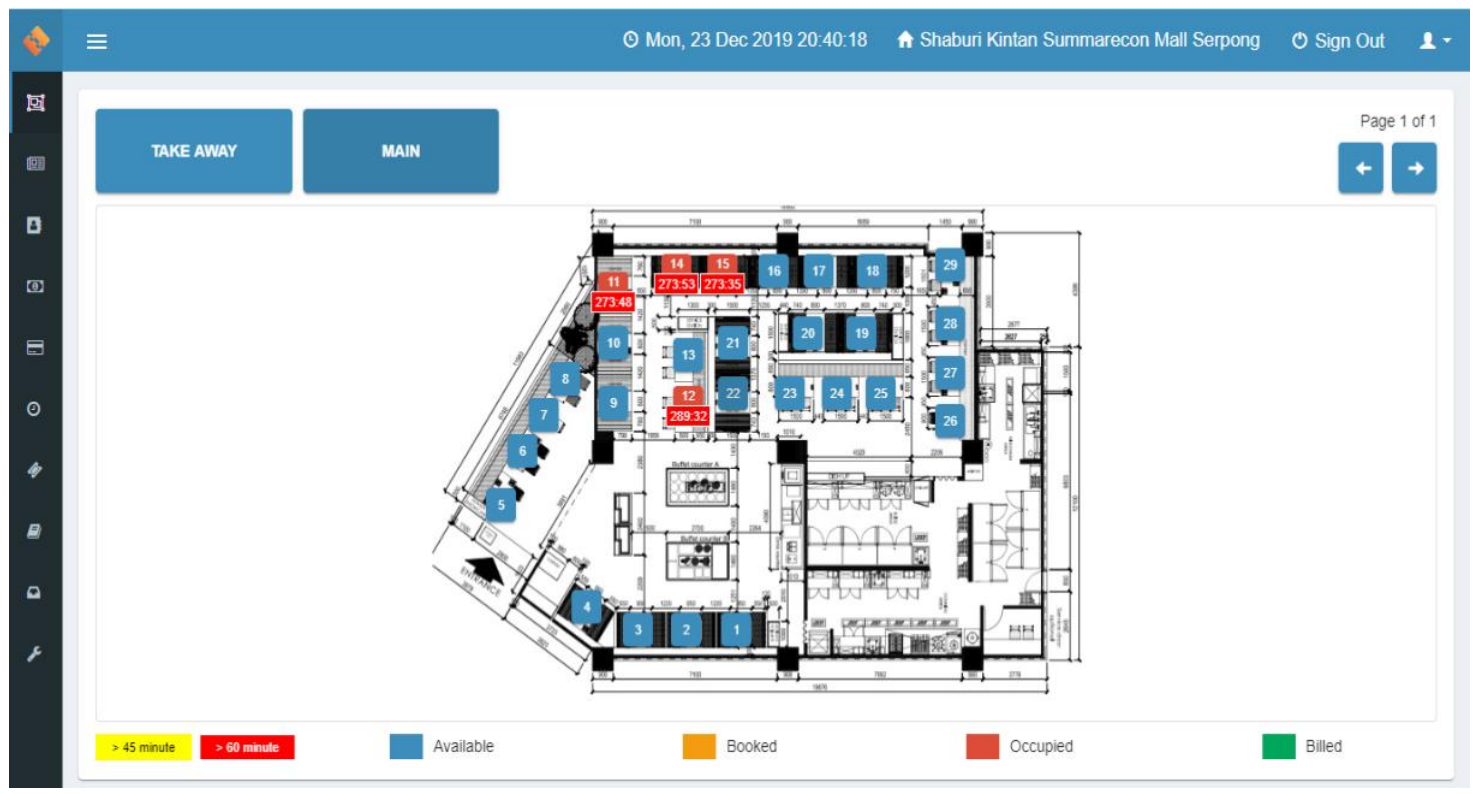

Figure 4. Main Page Display

In this main menu there is the same table layout information as in the login view, the difference in the login view can only be seen, while the main page view is done to place an order by clicking the blue button, or viewing the order by clicking the red button.

Display Order

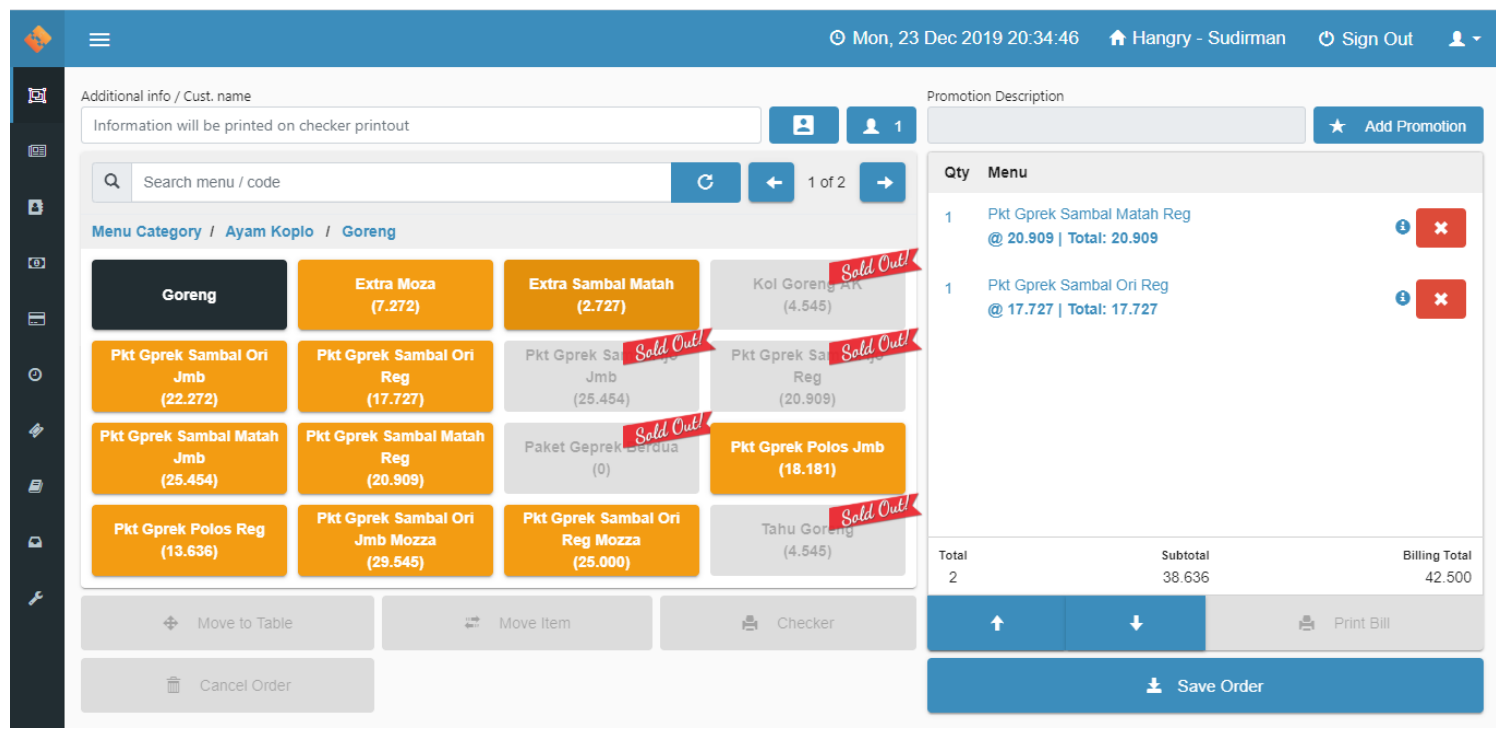

Figure 5. Display Order

In this view, cashier can input or cancel the customer order menu. 
Customer Display Order

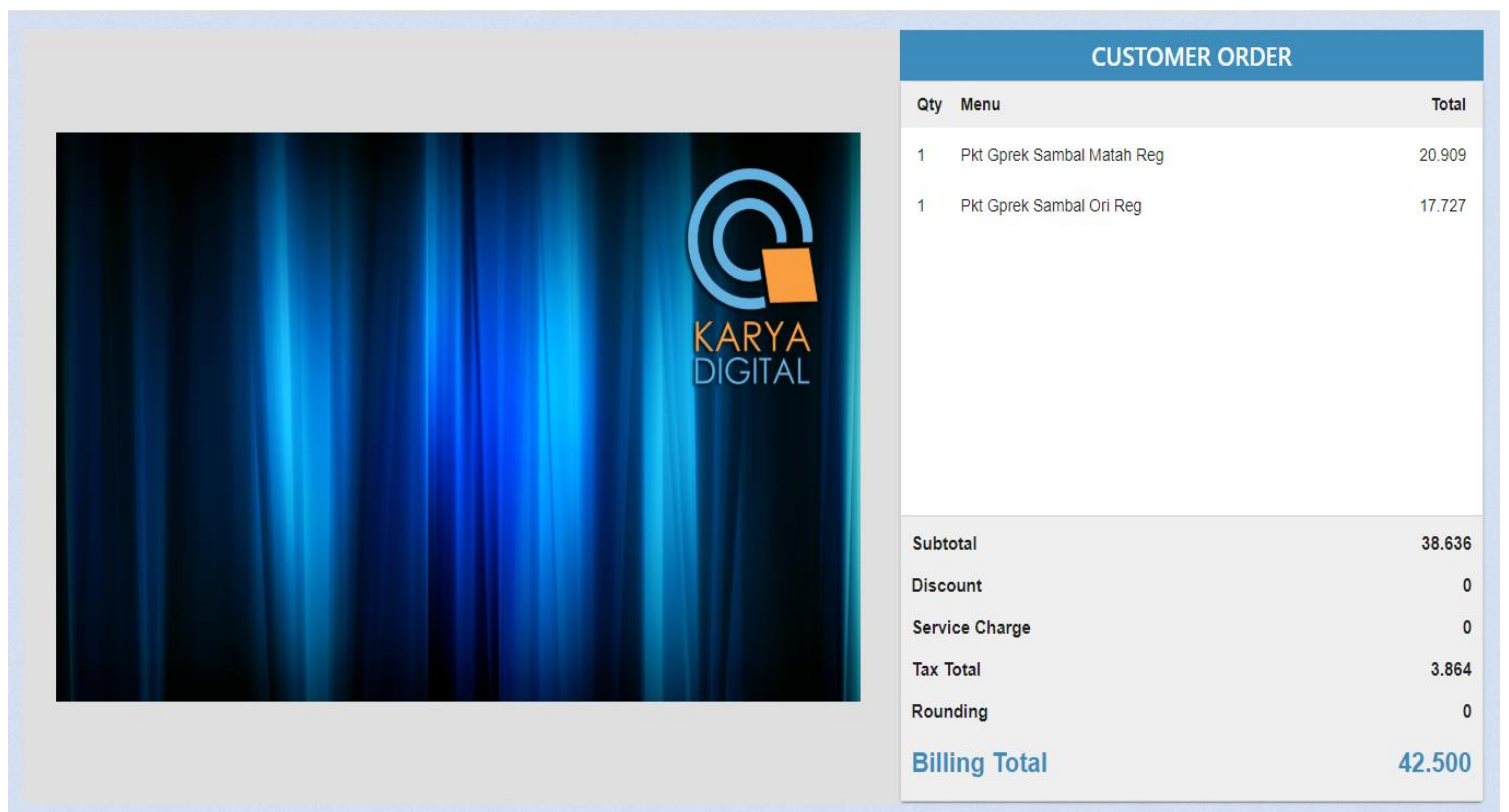

Figure 6. Customer Display Order

In this picture after cashier input customer orders will appear on this page.

Payment Display

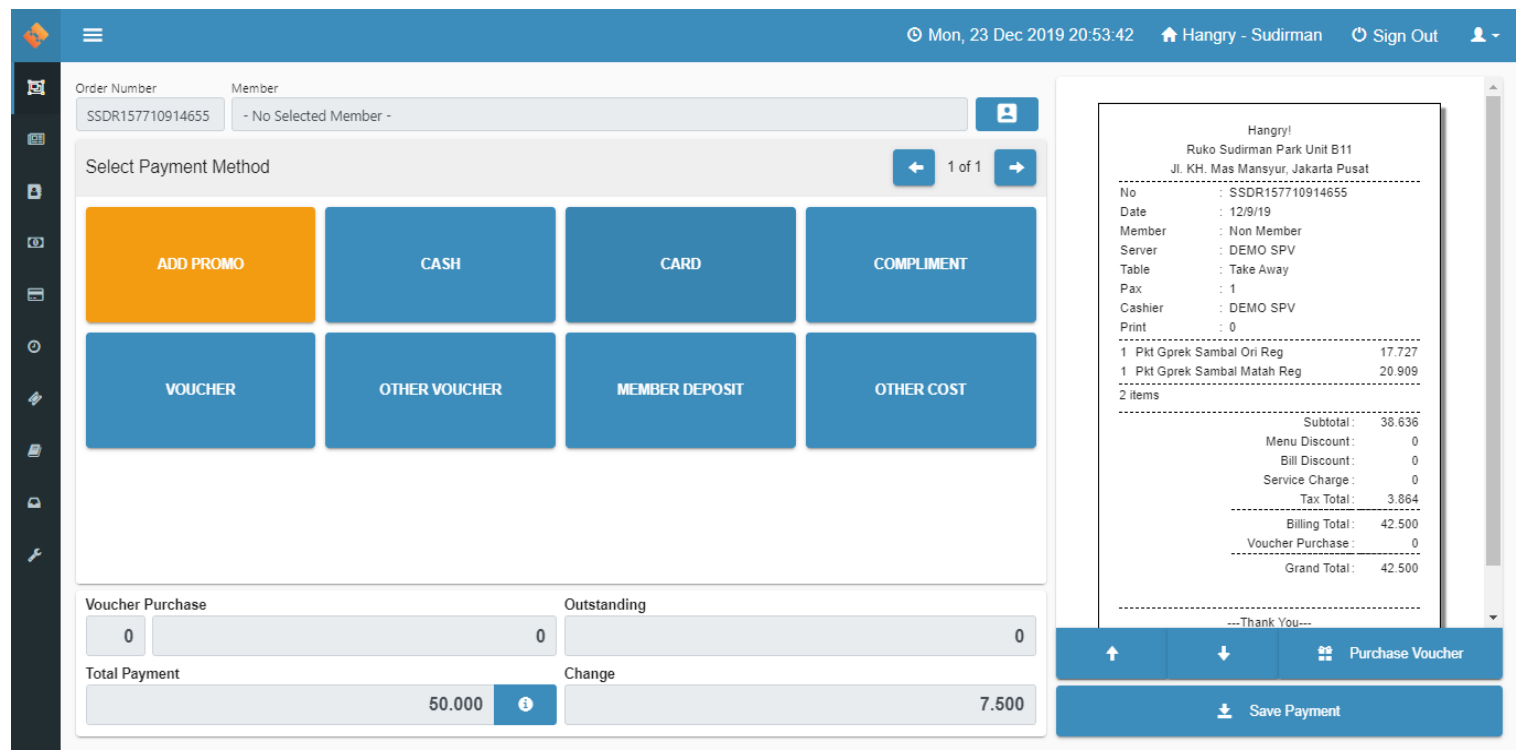

Figure 7. Payment Display

In the picture or menu is the display when the customer makes a payment.

\section{CONCLUSION}

Based on the results of the analysis of existing problems, especially in the asset management system at PT. Esensi Solusi Buana, the writer can conclude that the sales data processing system at PT. Esensi Solusi Buana's clients that have not been computerized gives somedifficulties for the company to find out the required sales data information, hence a 
computerized sales data processing system is made in order to record sales transactions on the clients of PT. Esensi Solusi Buana. There are frequent errors occur in the data input process and errors in sales transaction reports. Thus, the Point of Sales application is created to improve work efficiency so that it is able to create the required report results easily and more accurately.

\section{SUGGESTED}

This application design may still have many shortcomings. Therefore, it is necessary to improve in the future, that is the periodic evaluations of the system to be held for further development and improvement of the system with technological developments. With this point of sales application, it is expected that the clients of PT. Esensi Solusi Buana can participate to give some supports so that this application can run well later. Evaluation for the company is to change all manual systems with more computerized systems.

\section{REFERENCES}

[1] Cahyodi, Sapto Catur dan Rita Wahyuni Arifin. 2017. Sistem informasi Point Of Sales bebasis web pada Colony Amaranta Bekasi. Information System for Educators and Professionals Vol 1 No 2.

[2] Fitri, Kagome. 2016. Metode Analisis PIECES. Diakses pada 2 Juni 2020 dari http://fitrianieki.blogspot.com/2016/10/metode-analisis-pieces.html

[3] Hasan.2015.PERANCANGAN APLIKASI POINT OF SALE PADA MINI MARKET BINTANG MITRA PONTIANAK. Seminar Nasional Informatika Vol 1, No 1.

[4] Hidayat, dapai Ari. 2014. Rancang Bangun Aplikasi Point Of Sale (POS) Berbasis Web Dengan Pemanfaatan Trigger Pada Distribution Store CV NMRQ. Jurnal Sistem dan Teknologi Informasi Vol 2, No 2.

[5] Kusuma, Setiawan Budi.2017. PERANCANGAN DAN PEMBUATAN SISTEM APLIKASI POINT OF SALE BERBASIS WEBSITE PADA UD. ES DROP CITA RASA. Jurnal manajemen Informasi Vol 7, No 2.

[6] Lestariningati, Susmini Indriani. 2018. Mobile Point of Sale Design and Implementation. IOP Conference Series Materials Science and Engineering DOI 10.1088/1757-899X/407/1/012094.

[7] Yuarita, Titania Grawidi dan Fitri Mariska. 2017. Perancangan aplikasi Point Of Sales (POS) berbasis web menggunakan metode siklus hidup pengembangan sistem". Jurnal Teknologi \& Manajemen Informatika Volume 3, Nomor 2, Juli - Desember 2017.

[8] Sani, Annisa Septiana., Fajar Pradana., dan Denny Sagita Rusdianto. 2018. Pembangunan Sistem Informasi Point Of Sales Terintegrasi Dalam Lingkup Rumah Makan Beserta Cabangnya. Jurnal Pengembangan Teknologi Informasi dan Ilmu Komputer Vol. 2 No. 10, Oktober 2018, hlm.

[9] Susilo, E.A. 2018. Sistem Point Of Sales (P.O.S) Untuk Kasir Studi Kasus Indonesian Food "AA". Jurnal IJCCS.

[10] Wahyudi, Bawa., I.G.N. Alit Widana Putra,. dan Aulia Iefan Datya. 2017. Aplikasi Penjualan Point Of Sale (POS) Menggunakan Barcode Pada Koperasi Bina Kasih Sejahtera Berbasis Desktop Dengan First In First Out (FIFO). Jurnal Teknologi Informasi dan Komputer Vol 3, No 2.

[11] Wiguna, Putu Dika Arta., I Putu Agus Swastika., dan I Putu Satwika. 2018. Rancang Bangun Aplikasi Point of Sales Distro Management System dengan Menggunakan Framework React Native. Jurnal nasional teknologi dan sistem informasi Vol 4, N0 3 (2018). 